\section{„Czas wszystko zmienia...”? Wartość zmian i zmiana wartości \\ w sferze podróżowania \\ i ruchu turystycznego \\ w Czechosłowacji \\ w kontekście Aksamitnej \\ Rewolucji 1989/1990}

Wroctawski Rocznik Historii Mówionej Rocznik VII, 2017

ISSN 2084-0578 DOI: $10.26774 /$ wrhm.170

\begin{abstract}
Wstęp ${ }^{1}$
Tytuł niniejszego artykułu miał kilka źródeł inspiracji. Wielbiciele gry z konwencją rozpoznają, że pierwsza część pochodzi z refrenu legendarnej pieśni Boba Dylana, której czeska wersja była wykonywana przez popowe trio The Golden Kids (Helena Vondráčková, Marta Kubišová, Václav Neckář) pod koniec „złotych” lat sześćdziesiątych ${ }^{2}$. Chociaż ja sam nie upieram się, że historia ciągle się powtarza, wielu spośród tych, którzy tę epokę pamiętają, mogło mieć pod koniec lat 80 . XX w. wrażenie, że stanęli twarzą w twarz z czymś, co już kiedyś przeżyli. Późna faza dyktatury socjalistycznej, transformacja okresu pierestrojki, zakończona upadkiem tzw. komunizmu w Czechosłowacji w latach 1989/199o, była jednak dowodem, że po tych dwudziestu latach historia w istocie nie powtarza się, ale przeciwnie powstają zupełnie nowe ramy i jakości życia państwowego, społecznego
\end{abstract}

Tekst niniejszy powstał dzięki wsparciu projektu grantowego GA ČR o nazwie „«Malé» a «velké» dějiny českého/československého cestování a cestovního ruchu (1945-1989)” zarejestrowanego pod numerem 15-08130S.

2 W Polsce znanej z tekstem Agnieszki Osieckiej jako Czas wszystko zmienia w wykonaniu m.in. Maryli Rodowicz [przyp. tłum.]. 
150 i osobistego, niezależnie od tego, jakich określeń się użyje, charakteryzując tamten czas: „po rewolucji”, „po przewrocie”, „po upadku komunizmu”, ,postsocjalizm”, „postkomunizm”, „transformacja” itd. I d datego druga część tytułu - zapożyczona od słowackiej etnolożki Zuzany Profantovej - ma skłonić autora i czytelników do refleksji nad przemianą indywidualnie i kolektywnie rozumianych wartości, jakie ówcześni bohaterowie i świadkowie przypisują procesom i wydarzeniom, które tym zmianom (lub ich brakowi) towarzyszyły na przykładzie sfery podróżowania i ruchu turystycznego ${ }^{4}$.

Jak wskazuje wielu autorów prac historycznych, epokę rewolucji porównać można do gorączkowego „czasu przełomu”, pełnego zmian i zwrotów następujących niekiedy w ciągu kilku dni, godzin, a nawet minut ${ }^{5}$. W ówczesnym społeczeństwie istniało wiele politycznych, ekonomicznych, socjalnych czy kulturowych struktur, których owe dosyć gwałtowne, ale powierzchowne rewolucyjne zrywy nie zmieniły niemal wcale lub zmieniły dopiero w dłuższej perspektywie czasowej. Chociaż taka - nazwijmy to - strukturalistyczna perspektywa, którą w historiografii przypisać można m.in. przedstawicielom francuskiej szkoły Annales z Fernandem Braudelem na czele, może - pod wpływem postmodernistycznych wyzwań i „powrotu narracji” - wydawać się wyczerpana, to w połączeniu z analizą i interpretacją wykorzystującą m.in. oral history wydaje mi się jednak nadal inspirująca ${ }^{6}$. Przenikanie się czasów oraz nadawanie wydarzeniom

$3 \quad$ Np. M. Pullman, Konec experimentu. Přestavba a pád komunismu v Československu, Praha 2011; A. Gjuričová, M. Kopeček, Kapitoly z dějin české demokracie po roce 1989, Praha-Litomyšl 2008; L. Kopeček, Éra nevinnosti. Česká politika 1989-1997, Brno 2010.

$4 \quad$ Termin „podróżowanie” rozumieć będziemy jako indywidualną mobilność, w jakimkolwiek celu (turystyka rekreacyjna, odwiedziny u krewnych, podróże studyjne i służbowe), „ruch turystyczny” rozumieć będziemy jako dziedzinę (gospodarczą, ale także socjokulturową), której celem jest „goszczenie uczestników ruchu turystycznego, niezależnie od powodów podróży. Tytuł artykułu, zob.: Z. Profantová, Hodnota změny - změna hodnoty. Demarkační rok 1989, Bratislava 2009.

5 Szerzej zob. np.: J. Krapfl, Revolution with a Human Face: Politics, Culture, and Community in Czechoslovakia, 1989-1992, Ithaca and London 2013; J. Suk, Labyrintem revoluce - Aktérí, zápletky a křižovatky jedné politické krize (od listopadu 1989 do června 1990), Praha 2003.

$6 \quad$ Z inspiracji oryginalnych zob. np.: F. Braudel, La Mediterranee et le mondemediterraneen a l'epoque de Philippe II, Paris 1949, zob. także: idem, Ecrits sur l'histoire, Paris 1969. 
i procesom odmiennych znaczeń przez uczestników ówczesnego życia społecznego bardzo się bowiem zbliża do Braudelowskiej „wielowarstwowości” przeżywania, a także refleksji retrospektywnej ${ }^{7}$. Także z tego powodu badania prowadzone metodą oral history mogą stać się jednym z narzędzi jakościowego poznania problematyki; narzędziem, z którego obecnie często korzystamy w projekcie grantowym o historii podróżowania i ruchu turystycznego w latach 1945-1989 w Czechosłowacji, przekonani, że kryje ono w sobie olbrzymi potencjał.

\section{Obiektywne ramy $\mathrm{i}$ trendy $\mathrm{w}$ historii podróżowania}

\section{i ruchu turystycznego końca lat 80 . XX w.}

Ramy przemian wyznacza między innymi sytuacja międzynarodowa, jak już dziś wiemy - ostatnia faza zimnej wojny. Zbliżenie polityczne, ekonomiczne i kulturalne między Wschodem a Zachodem, a także wewnętrzne przemiany w Związku Radzieckim i w krajach „przyjaciół pokoju i socjalizmu” w związku z polityką pierestrojki i głasnosti, przenikały także w ograniczonym zakresie do realiów czechosłowackich ${ }^{8}$. Z jednej strony były to postępujące stopniowo próby liberalizacji dosyć rygorystycznej w innych obszarach centralnie planowanej gospodarki, w tym zezwolenie na drobną inicjatywę prywatną w wybranych zakładach czy na zakładanie firm z udziałem zagranicznym (joint ventures), z drugiej - stałe dążenie wielu protagonistów reżimu do stosowania skostniałych ideologicznych mierników w najróżniejszych obszarach życia społecznego (np. polityka, kultura) i dalszego mocnego trzymania w rękach steru władzy w tych dziedzinach (np. obszar polityki podróży zagranicznych). Ta sytuacja plasowała Czechosłowację w Europie Środkowej i Wschodniej wśród raczej konserwatywnie nastawionych reżimów „realnego socjalizmu”, w wielu

7 Z klasyków refleksji na temat przemian pamięci i jej znaczenia nawiązałbym np. do prac włoskiego amerykanisty i badacza oral history Alessandra Portellego. Zob.: A. Portelli, The Death of Luigi Trastulli and Other Stories: Form and Meaning in Oral History, Albany 1991; idem, The Battle of Valle Giulia: Oral History and the Art of Dialogue, Madison 1997; najnowsze zob.: idem, They Say in Harlan Country: An Oral History, New York-Oxford 2010.

${ }_{8} \quad$ Np. J. Vykoukal, B. Litera, M. Tejchman, Východ. Vznik, vývoj a rozpad sovětského bloku 1944-1989, Praha 20oo; T. Judt, Poválečná Evropa. Historie po roce 1945, Praha 2008; A. Zubov, Déjiny Ruska 20. století II díl (1939-2007), Praha 2015. Z perspektywy oral history np. D. Raleich, Soviet Babyboomers. An Oral History of Russia's Cold War Generation, New York-Oxford 2013. 
152 aspektach może nawet paradoksalnie bardziej rygorystycznych niż wieloletni wzór, sam Związek Radziecki ${ }^{9}$.

Kategorią, która przez dziesięciolecia kształtowała się w kręgu cywilizacji euroamerykańskiej i którą należy zaliczyć do trendów długoterminowych, jest bez wątpienia „społeczeństwo czasu wolnego” (leisure society). W kontekście ruchu turystycznego lat 8o. do jego najbardziej widocznych przejawów należało umasowienie ruchu turystycznego na skalę międzynarodową, wzrost popularności spędzania urlopów w krajach zamorskich, korzystanie z czarterowych połączeń lotniczych czy postępująca automatyzacja i integracja oferty i administrowania usługami dzięki nowym moźliwościom komunikacyjnym, a także powszechne dążenie do „racjonalizacji kosztów”. Trzeba koniecznie podkreślić, że w Czechosłowacji kategoria ta budowana była w kontekście rzeczywistości „socrealistycznej” i różniła się w wielu aspektach od modelu zachodniego. Dotyczyło to między innymi spóźnionego i limitowanego rozwoju krajowej turystyki samochodowej, popularności tzw. drugiego domu (habitatu) (tzn. chat i chałup [wiejskich domów weekendowych, najczęściej przedwojennych i zaniedbanych, powszechnie nabywanych przez mieszkańców miast w latach 70. XX w. i samodzielnie przez nich remontowanych - ten fenomen przerodził się w specyficzny styl życia, nie spotykany na taką skalę poza granicami Czechosłowacji - przyp. tłum.]), limitowanej oferty i jakości towarów i usług czy wciąż istniejącego nacisku na dotowanie „socjalnych form” spędzania wolnego czasu (np. w formie wsparcia wypoczynku krajowego i zagranicznego czy ułatwienia pobytów leczniczych w sanatoriach). W końcu lat 8o. również u nas widać stopniowe narastanie akceptacji trendów zorientowanych komercyjnie i konwergencji modelu „socrealistycznego” w kierunku (domniemanych) wzorów zachodnich, takich jak np. zwiększający się popyt na rozszerzanie oferty biur podróży czy noclegów w kwaterach prywatnych i w krajowych centrach turystycznych itp.

$9 \quad$ Np. J. Rychlík, Cestování do ciziny v habsburské monarchii a v Československu: pasová, vízová a vystěhovalecká politika 1848-1989, Praha 2007; V. Průcha [et al.], Hospodářské a sociální dějiny Československa. 1918-1992, 2. díl, 1945-1992, Brno 2009. 


\section{$\mathrm{i}$ ich punkty widzenia $\mathrm{w}$ badaniach oral history}

W kontekście badań oral history można przypomnieć, że „pamięci mobilności" dotyczyły już w naszych krajach projekty Centrum Oral History Instytutu Historii Współczesnej Akademii Nauk Republiki Czeskiej [Centrum orální historie Ústavu pro soudobé dějiny AV ČR, dalej: $\mathrm{COH}$ ] realizowane przede wszystkim po 2006 r., które dotyczyły historii konkretnych grup zawodowych i ogólnie historii współczesnej społeczeństwa czeskiego. Pomijając przedstawicieli „podróżujących” zawodów, we wspomnieniach każdej narratorki i narratora podróżowanie traktowane było bardzo indywidualnie: od aktywności rzekomo bardzo swego czasu oczekiwanej i popularnej, po temat indyferentny czy wręcz niepopularny. Priorytety życia i pamięci tych „zwyczajnych ludzi”, urodzonych mniej więcej w latach 1930-1955 (generacja „hitlerowskich” i „stalinowskich” dzieci), warto by było porównać z młodszymi pokoleniami, urodzonymi w latach 6o. i 70. XX w. („dzieci Praskiej Wiosny” i „dzieci ery Husaka”) ${ }^{10}$. Pewne próby w tym kierunku były już podjęte przed laty w ramach projektu „Wysepki Wolności” i dotyczyły młodego pokolenia dorastającego w latach 80 ., zatem można by je kontynuować także w przyszłości ${ }^{11}$. Zwłaszcza że analiza stopniowo rozbudowywanych wywiadów (prowadzonych przez studentów Wydziału Nauk Humanistycznych Uniwersytetu Karola w Pradze) pozwala na bardzo ciekawe porównania z narracją przedstawicieli „pokolenia pierestrojki i Aksamitnej Rewolucji", urodzonych w latach 8o. i na początku 9o. XX w.

Jako jedno z kolejnych wyzwań rozwoju badawczego $\mathrm{COH}$ jawić się może przeprowadzenie i analiza wywiadów z przedstawicielami dawnych elit komunistycznych i protagonistami z szeregów opozycji i środowisk dysydenckich lat 70. i 80. XX w. ${ }^{12}$ Badania takie, realizowane po raz pierwszy w latach 2002-2004, odsłoniły bowiem wiele nierozpoznanych dotychczas stron "nie-zawodowego" i codziennego życia „zwycięzców” i „pokonanych”

10 Więcej o definicji terminu „zwykli ludzie”, zob. M. Vaněk, Obyčejní lidé...?! Pohled do života tzv. mlčící většiny. Životopisná vyprávění př́slušníků dělnických profesí a inteligence, Praha 2009, s. 10-17.

$1 \quad$ Idem, Ostrůvky svobody. Kulturní a občanské aktivity mladé generace v 8o. letech $v$ Československu, Praha 2002.

12 M. Vaněk, P. Urbášek, Vitězové? Poražení; M. Vaněk, Mocní? a Bezmocní? Politické elity a disent $v$ období tzv. normalizace. Interpretační studie životopisných interview, Praha 2006. 
154 Aksamitnej Rewolucji 1989 r., chociaż głównym tematem rozmów było przede wszystkim życie zawodowe i kariery polityczne narratorów i narratorek. Interesujące byłoby bez wątpienia poznanie osobistych spostrzeżeń członków nomenklatury z podróży służbowych za granicę, ewentualnie fenomenu partyjnych form rekreacji, jak również ogólnie - zagłębienie się $\mathrm{w}$ historię spędzania czasu wolnego ${ }^{13}$. Biorąc pod uwagę dotychczasowe mainstreamowe postrzeganie w dyskursie pamięci i dyskursie historycznym okresu „normalizacji” jako epoki swoistego „bezczasu” i generalnej "ucieczki od życia publicznego" do sfery rodziny i czasu wolnego w perspektywie rozwoju społeczeństwa konsumpcyjnego, wart zainteresowania byłby również bardziej szczegółowy wgląd w życie członków opozycji i dysydentów. Na podstawie dotychczasowych badań wydaje się bowiem, że chociaż wielu z nich bardzo gwałtownie odcinało się (trzeba przyznać, że raczej ex-post po 1989 r.) od „znormalizowanej” większości społeczeństwa, to cały szereg ówczesnych aspektów ich życia codziennego i stylu życia w ogólności pozostaje raczej w zgodzie niż w opozycji do życia „milczącej większości” ówczesnej Czechosłowacji (np. wycieczki samochodowe, wyjazdy do domów weekendowych, konsumpcja alkoholu i wyrobów tytoniowych $)^{14}$.

Jednym z celów trzyletniego projektu finansowanego przez Agencję Grantową Republiki Czeskiej pt. „«Mała» i «wielka» historia czeskiego/ czechosłowackiego podróżowania i ruchu turystycznego (1945-1989)", realizowanego obecnie przez $\mathrm{COH}$, jest rejestracja doświadczeń i wspomnień narratorów wyjeżdżających służbowo za granicę, także tych zatrudnionych w ruchu turystycznym. W przypadku „podróżujących” zawodów kwestia wyjątkowości podróży jest - w przeciwieństwie do „niepodróżującej większości" - de facto nieistotna, pytania powinny dotyczyć raczej ich osobistych preferencji - dokąd jeździli najczęściej, dokąd wyjątkowo, dokąd najchętniej czy odwrotnie - najmniej chętnie, a to wszystko uzupełnione obligatoryjnym pytaniem „dlaczego"? Jak wskazują niektóre poprzednie badania, podejmowana często $\mathrm{w}$ dyskursie publicznym kwestia emigracji

13 Z inspiracji zagranicznych, zob.: I. Duda, I. Stanić, Tanned guardians, followers and pioneers: Yugoslav directed tourism across Tito's Brijuni Islands, „Journal of Tourism History", 6 (2014), nr 2-3, s. 174-193.

14 Np. P. Schnidler-Wisten, Rodinné prostředí př́slušníků politických elit a disentu, [w:] Mocní? a Bezmocní? Politické elity a disent v období tzv. normalizace. Interpretační studie životopisných interview, red. M. Vaněk, Praha 2006, s. 205-235. 
narratorom z tej grupy jawi się jako zupełnie bez znaczenia, dlatego warto

pytać ich również o to dlaczego potencjalna emigracja nie była przez nich przed 1989 r. brana pod uwagę itd. ${ }^{15}$

Natomiast nawet mimo upływu ponad 25 lat nadal bardzo wrażliwe, a niekiedy wręcz stanowiące tabu są wśród reprezentantów zawodów „podróżujących” tematy związane z przemytem i „czarnym” (zazwyczaj wymiennym) handlem towarami, które w odwiedzanych krajach albo w ówczesnej Czechosłowacji były deficytowe ${ }^{16}$. Ten element ówczesnych podróży zagranicznych daje niezwykle interesujący obraz nieoficjalnych „map podróżnych” i hierarchii popularności odwiedzanych krajów ze względu na indywidualną „detaliczną” działalność. Uprawiała ją - oczywiście w miarę możliwości także większość populacji, jednak, jak jasno wynika ze szczegółowych badań, przedstawiciele „podróżujących zawodów” mieli tu zdecydowanie więcej okazji i, co za tym idzie, zdobyli o wiele większe doświadczenie ${ }^{17}$.

Podobnie wśród pracowników w branży hotelarskiej i ruchu turystycznego kwestię drażliwą stanowi niekiedy „szczególne traktowanie” gości w zależności od narodowości, a zwłaszcza dzielenie klientów na „cudzoziemców dewizowych” i resztę. Z niektórych wspomnień jasno wynika, że także te kontakty bywały niekiedy wykorzystywane do "handlu wymiennego" czy też przyczyniły się do powstania systemu "podwójnych cen”, funkcjonującego na niekorzyść „zachodnich” cudzoziemców. Również ewentualne (i możliwie subtelne) pytanie o motywy takich praktyk wydaje się bardzo inspirujące ${ }^{18}$. Kolejny krąg delikatnych tematów, na które trafiliśmy w dotychczasowych badaniach, koncentruje się wokół kwestii doboru kadr (czy przeciwnie nie-doboru) w pewnych zawodach i potencjalny wymóg (lub przeciwnie - jego brak) przynależności partyjnej i zaangażowania

15 Np. L. Krátká, Z Prahy až na konec světa. Životní pout pracovníků zahraničního obchodu, [w:] Př́běhy (ne)obyčejných profesí: česká společnost v období tzv. normalizace a transformace, red. M. Vaněk, L. Krátká, Praha 2014, s. 230-271; L. Krátká, A History of the Czechoslovak Ocean Shipping Company, 1948-1989: How a Small, Landlocked Country Ran Maritime Business During the Cold War, Stuttgart 2015.

${ }_{16}$ O handlu przez granice np. J. Kučera, Postranní cesty - Schleichwege - drogi boczne - köztes terei. Neoficiální kontakty mezi občany socialistických zemí v letech 1945-1989, "Soudobé dějiny“, XVII (2010), nr 3, s. 309 nn.

$17 \quad$ L. Krátká, $A$ History...

18 P. Houda, Socialistické pohostinství: ideál veřejného stravování zdevastovaný praxí, [w:] Př́běhy (ne)obyčejných profesí..., s. 352-379. 
w życie publiczne ${ }^{19}$. Często bowiem pojawia się tu optyka zupełnie różna od tej, do której przywykliśmy w ramach popularnego dyskursu (uznając zawody „podróżujące” za „skorumpowane” czy „kolaborujące z reżimem”). Ogólnie można bowiem powiedzieć, że w pamięci wielu narratorów podróżowanie za granicę czy kontakt z cudzoziemcami stanowiły całkiem zwyczajną część życia zawodowego i budowania kariery niezależnie od realiów epoki. Dlatego też zdecydowaliśmy się dostosować styl pytań do tych ówczesnych i wspomnieniowych aspektów, a także zwrócić szczególną uwagę na budowanie kręgów tematycznych w przypadku wywiadów półotwartych z przedstawicielami tych zawodów.

Ostatnie wielkie wyzwanie, które mogłoby wzbogacić perspektywę badań oral history, ale także ogólniej - historycznych, związane jest z rozszerzeniem badań na przedstawicieli innych narodów, co prawdopodobnie najłatwiej będzie przeprowadzić w ramach przyszłych projektów międzynarodowych. Nowy wymiar, który częściowo naświetla literatura wspomnieniowa, a częściowo niektóre zrealizowane już projekty oral history, miałoby stanowić uchwycenie perspektywy pamięci i doświadczenia z podróży obywateli obcych państw - zarówno ze Wschodu, jak i z Zachodu przyjeżdżający w różnych celach do Czechosłowacji ${ }^{20}$.

\section{Na zakończenie, czyli jaką granicą był w historii podróżowania i ruchu turystycznego rok 1989}

Z dotychczasowych badań oral history poświęconych historii społeczeństwa czeskiego widać, że dla większości narratorów rok 1989 stanowi punkt odniesienia, o który w nagranych wywiadach opiera się często konstrukcja

19 O postawach wobec wymogu zaangażowania politycznego i publicznego, zob. np. M. Vaněk, „Jak jsme budovali socialismus a potom kapitalismus... Tak jste to myslel?" Profesí osudy hospodářských elit v době tzv. normalizace a na počátku transformace, [w:] Příběhy (ne)obyčejných profesí..., s. 178-228; L. Krátká, Z Prahy až na konec světa... O (pośrednich i bezpośrednich) aluzjach do trwałego niedoboru personelu np. w sektorze hotelarskim aż do końca lat 8o. np. A. Kounovský, Vnitřní obchod v závěru 7. pětiletky, "Československé pohostinství a cestovní ruch“, 31 (1985), nr 1, s. 1; R. Kratoch, Slovo k přestavbě, „Československé pohostinství a cestovní ruch“, 33 (1987), nr 11, s. 235.

20 Z literatury wspomnieniowej np. R. Chenu, Žit svobodně je umění. (Československý deník 1969-1980), Praha 2007; z perspektywy oral history relacje cudzoziemców żyjących w Czechosłowacji, np. T. Mašková, „Západni“ cizinci v normalizačním Československu, praca dyplomowa, Praha 2013. 
wspomnień, nie wyłączając tych dotyczących tematu podróżowania ${ }^{21}$. Oczywiście w tym kontekście wielką rolę odgrywa wpływ pamięci zbiorowej, czy w tym przypadku pokoleniowej narratorów urodzonych mniej więcej w latach 1935-1955. Jednak z sond badawczych, odnoszących się do narratorów młodszych, np. urodzonych w latach 8o., wynika, że dla nich rok 1989 często nie odgrywa już takiej roli, a zwłaszcza gdy chodzi o osoby urodzone w drugiej połowie tej dekady - stała się ona dla nich niemal „zwykłą datą" w podręczniku historii.

W poprzedniej części zauważyłem, że narratorzy wywodzący się z „zawodów podróżujących", a także pracownicy branży hotelarskiej i ruchu turystycznego widzą wydarzenia końca lat 8o. poniekąd z innej perspektywy i nadają im wartość inną niż większość społeczeństwa. Jak wskazują poprzednie studia $\mathrm{z}$ historii hotelarstwa, liberalizacja w dziedzinie działalności gospodarczej, przypisywana dopiero transformacji ekonomicznej po 1989 r., często polega na akceleracji rozwiązań wdrożonych w okresie pierestrojki ${ }^{22}$. Dlatego też uczestnicy tych wydarzeń widzą nie tyle zmianę, ile kontynuację. W perspektywie zawodowej kontynuacja oznacza dalszy kontakt z gośćmi (czy to z cudzoziemcami, czy rodakami), chociaż w epoce polistopadowej, szczególnie w głównych centrach turystycznych kraju (wielkie miasta na czele ze Pragą, czeskie, morawskie i śląskie góry, uzdrowiska), dała się odczuć nasilająca się ekspansja gości zagranicznych, a później także wielki powrót obywateli czeskich, którzy z wielu powodów zaczęli wracać do znanych i sprawdzonych miejsc. Za kontynuację codziennej praktyki u szeregu narratorów zatrudnionych w ruchu turystycznym i hotelarstwie uznać należy podejście rynkowe i choćby stawianie na pierwszym miejscu wartości pieniądza. Dziś taka postawa może wydawać się banalną oczywistością. Jeżeli jednak weźmie się pod uwagę, że „nauka zasad gospodarki rynkowej” na wszystkich poziomach po 1989 r. nie była w społeczeństwie czeskim traktowana jak niezbędna konieczność, dostrzeżemy, że dla wielu protagonistów (podobnie jak dla dążących do wprowadzenia innowacyjnych metod i narządzi menedżerów ówczesnych państwowych firm) te cechy były istotne ${ }^{23}$.

21 Np. M. Vaněk, Obyčejní lidé...

22 Np. P. Houda, Socialistické pohostinství...

23 O „wyzwaniach epoki transformacji” na płaszczyźnie idei i wartości np. V. Bělohradský, Kapitalismus a občanské ctnosti, Praha, Československý spisovatel 1992; O „uczeniu się kapitalizmu” z perspektywy narratorów np. P. Houda, Socialistické pohostinství...; M. Vaněk, „Jak jsme budovali socialismus... 
Wracając do bardziej ogólnej refleksji nad znaczeniem roku 1989, szczególnie w obszarze podróżowania, dla starszej generacji epoka polistopadowa oznaczała możliwość swobodnych wyjazdów za granicę. W perspektywie wspomnień widać to na przykład przy opisie pierwszych chwil polistopadowego boomu turystycznego skierowanego za żelazną kurtynę (najczęściej w formie podróży do sąsiedniej Austrii czy Niemiec w pierwszych tygodniach, miesiącach czy latach po rewolucji), któremu narratorzy nadają wielkie znaczenie symboliczne. Jeszcze po dziesięcioleciach potrafią z podnieceniem opowiadać o wrażeniach z tych podróży wraz z drobnymi szczegółami (prawdziwymi czy domniemanymi). Także dlatego przy retrospektywnym porównaniu „za” i „przeciw” (epoki „przed” i „po”) podróże zagraniczne bywają wskazywane jako jedna z najważniejszych "zdobyczy nowej epoki"24.

Po Aksamitnej Rewolucji u wielu narratorów (ale też ogólnie w społeczeństwie jako całości) dochodzi zarówno do kompensacji symbolicznego „głodu podróży”, powstałego w minionej epoce, jak i do „demitologizacji” jednej z wartości, która była częścią składową systemu symbolicznych barier zimnej wojny: „magicznego świata Zachodu”25. Zaczyna się ona rozpływać między innymi pod wpływem wymiany informacji, fali zachodnich turystów i pracowników, ale także dzięki podróżom na Zachód, niezależnie od tego, jakie były poprzednie indywidualne wyobrażenia o tym, jak to na Zachodzie wygląda. „Zachód” i podróże „na Zachód” (czy to przez granice, czy na miejscu $\mathrm{w}$ formie wizyt w centrach handlowych czy rozrywkowych) tracą w oczach starszej generacji narratorów i narratorek swoją wyjątkowość, co sprawia, że ich spojrzenie upodabnia się do poglądów narratorów młodego pokolenia, które już w zasadzie przywykło do („normalnych”) zwyczajów i standardów podróżowania przyjętych w zachodnich demokracjach liberalnych. Zwyczajów i standardów, w których mobilność i udział w ruchu turystycznym zależne są - obok indywidualnych preferencji - od możliwości zdrowotnych, czasowych czy finansowych - a więc od wartości „nowej” epoki.

Tłumaczenie z języka czeskiego

Katarzyna Uczkiewicz

24 Więcej: M. Vaněk, P. Mücke, Velvet Revolutions: An Oral History of Czech Society, New York-Oxford 2016.

25 Np. A. Yurchlak, Everything Was Forever, Until It Was No More. The Last Soviet Generation, Princeton 2006. 
Bělohradský V., Kapitalismus a občanské ctnosti, Praha 1992

Braudel F., Ecrits sur l'histoire, Paris 1969

Braudel F., La Mediterranee et le mondemediterraneen a l'epoque de Philippe II, Paris 1949

Chenu R., Žít svobodně je umění. (Československý deník 1969-1980), Praha 2007

Duda I., Stanić I., Tanned guardians, followers and pioneers: Yugoslav directed tourism across Tito's Brijuni Islands, „Journal of Tourism History”, 6 (2014), nr 2-3, s. 174-193

Gjuričová A., Kopeček M., Kapitoly z dějin české demokracie po roce 1989, Praha-Litomyšl 2008

Houda P., Socialistické pohostinství: ideál veřejného stravování zdevastovaný praxí, [w:] Př́běhy (ne)obyčejných profesí: česká společnost vobdobí tzv. normalizace a transformace, red. M. Vaněk, L. Krátká, Praha 2014, s. 352-379

Judt T., Poválečná Evropa. Historie po roce 1945, Praha 2008

Kopeček L., Éra nevinnosti. Česká politika 1989-1997, Brno 2010

Kounovský A., Vnitřní obchod v závěru 7. pětiletky, „Československé pohostinství a cestovní ruch", 31 (1985), nr 1

Krapfl J., Revolution with a Human Face: Politics, Culture, and Community in Czechoslovakia, 1989-1992, Ithaca and London 2013

Krátká L., A History of the Czechoslovak Ocean Shipping Company, 1948-1989: How a Small, Landlocked Country Ran Maritime Business During the Cold War, Stuttgart 2015

Krátká L., Z Prahy až na konec světa. Životni pout’ pracovníků zahraničního obchodu, [w:] Př́běhy (ne)obyčejných profesí: česká společnost v období tzv. normalizace a transformace, red. M. Vaněk, L. Krátká, Praha 2014, s. 230-271

Kratoch R., Slovo k přestavbě, „Československé pohostinství a cestovní ruch”, 33 (1987), nr 11

Kučera J., Postranní cesty - Schleichwege - drogi boczne - köztes terei. Neoficiální kontakty mezi občany socialistických zemí v letech 1945-1989, „Soudobé dějiny”, XVII (2010), nr 3, s. 307-311

Mašková T., „Západni” cizinci v normalizačním Československu, praca dyplomowa, Praha 2013 Mocní? a Bezmocní? Politické elity a disent v období tzv. normalizace. Interpretační studie životopisných interview, red. M. Vaněk, Praha 2006

Portelli A., The Battle of Valle Giulia: Oral History and the Art of Dialogue, Madison 1997

Portelli A., The Death of Luigi Trastulli and Other Stories: Form and Meaning in Oral History, Albany 1991

Portelli A., They Say in Harlan Country: An Oral History, New York-Oxford 2010

Příběhy (ne)obyčejných profesí: česká společnost v období tzv. normalizace a transformace, red. M. Vaněk, L. Krátká, Praha 2014

Profantová Z., Hodnota změny - změna hodnoty. Demarkační rok 1989, Bratislava 2009

Průcha V. [et al.], Hospodářské a sociální dějiny Československa. 1918-1992, 2. díl, 1945-1992, Brno 2009 
Raleich D., Soviet Babyboomers. An Oral History of Russia's Cold War Generation, New YorkOxford 2013

Rychlík J., Cestování do ciziny v habsburské monarchii a v Československu: pasová, vizová a vystěhovalecká politika 1848-1989, Praha 2007

Schnidler-Wisten P., Rodinné prostředí př́slušníků politických elit a disentu, [w:] Mocní? a Bezmocní? Politické elity a disent v období tzv. normalizace. Interpretační studie životopisných interview, red. M. Vaněk, Praha 2006, s. 205-235

Suk J., Labyrintem revoluce - Aktérii, zápletky a křižovatky jedné politické krize (od listopadu 1989 do června 1990), Praha 2003

Vaněk M., „Jak jsme budovali socialismus a potom kapitalismus... Tak jste to myslel?" Profesí osudy hospodářských elit v době tzv. normalizace a na počátku transformace, [w:] Př́běhy (ne) obyčejných profesí: česká společnost v období tzv. normalizace a transformace, red. M. Vaněk, L. Krátká, Praha 2014, s. 178-228

Vaněk M., Obyčejní lidé...?! Pohled do života tzv. mlčicí většiny. Životopisná vyprávění příslušníků dělnických profesí a inteligence, Praha 2009

Vaněk M., Ostrůvky svobody. Kulturní a občanské aktivity mladé generace v 8o. letech v Československu, Praha 2002

Vaněk M., Mücke P., Velvet Revolutions: An Oral History of Czech Society, New York-Oxford 2016

Vaněk M., Urbášek P., Vitězové? Poražení, [w:] Mocní? a Bezmocní? Politické elity a disent v období tzv. normalizace. Interpretační studie životopisných interview, red. M. Vanek, Praha 2006

Vykoukal J., Litera B., Tejchman M., Východ. Vznik, vývoj a rozpad sovětského bloku 1944-1989, Praha 2000

Yurchlak A., Everything Was Forever, Until It Was No More. The Last Soviet Generation, Princeton 2006

Zubov A., Dějiny Ruska 2o. století II díl (1939-2007), Praha 2015 
The article tries to resume the main contours and changes in the travelling and tourism "sphere" in the consequences of Velvet Revolution and the fall of communism in Czechoslovakia. The most important historical frames of "sphere" development are presented, as well as the key perspectives and meanings deriving from realized oral history interviews. For conclusion the author tries to resume and "re-think" the issue of "historical meaning” and the importance of the 1989 change in the context of Czech contemporary history.

Key words: contemporary history, oral history, travelling, tourism, Czechoslovakia
Pavel Mücke

"Time changes everything..." The value of changes and change in values in the area of travel and tourism in Czechoslovakia in the context of the Velvet Revolution of 1989/1990

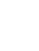

